\title{
PENGARUH VARIASI PERENDAMAN UDANG VANAME (Litopenaeus vannamei) DALAM ASAM BUAH ALAMI TERHADAP PENURUNAN KADAR TIMBAL (Pb) DI TAMBAK TRADISIONAL PASIR SAKTI LAMPUNG TIMUR
}

\author{
Devi Susilawati ${ }^{1}$ Hening Widowati ${ }^{2}$ Widya Sartika Sulistiani ${ }^{3}$ \\ 1,2,3 Universitas Muhammadiyah Metro \\ ${ }^{1}$ Email: susilawatidevi99@gmail.com ,2Email: hwummetro@gmail.com, ${ }^{3}$ Email: \\ widya.sulistiani@gmail.com
}

\begin{abstract}
Abstrak: Asam buah alami merupakan buah yang bercita rasa asam mengandung asam organik salah satunya asam sitrat, contoh asam buah alami yaitu asam jawa, jeruk nipis, jeruk lemon, buah nanas. Asam buah alami dapat dimanfaatkan sebagai bahan untuk merendam bahan pangan yang berasal dari produk perikanan untuk menghilangkan bau amis dan memberikan oroma pada masakan oleh masyarakat. Tujuan penelitian ini adalah untuk mengetahui pengaruh perendaman asam buah alami terhadap penurunan kadar timbal $(\mathrm{Pb})$ pada udang Vanamae, mengetahui variasi perendaman paling berpengaruh menurunkan kadar timbal pada udang Vanamae. Penelitian ini menggunakan metode ekperimen dengan rancangan acak kelompok lengkap (RAKL). Percobaan dilakukan dengan 5 perlakuan, adalah Kontrol (200 gram udang tanpa perendaman), Perlakuan 1 (200 gram udang $+25 \mathrm{ml}$ asam jawa), Perlakuan 2 (200 gram udang $+25 \mathrm{ml}$ jeruk nipis), Perlakuan 3 (200 gram udang $+25 \mathrm{ml}$ jeruk lemon), dan Perlakuan 4 (200 gram udang $+25 \mathrm{ml}$ nanas), setiap perlakukan diberikan masing-masing 4x ulangan. Berdasarkan analisis uji anava didapatkan hasil $\mathrm{F}_{\text {hit }}>\mathrm{F}_{\text {daf }}$ disimpulkan terdapat pengaruh perendaman asam buah alami terhadap penurunan kadar timbal $(\mathrm{Pb})$ pada daging udang Vaname, perendaman dengan asam jeruk nipis paling signifikan untuk menurunkan kadar logam timbal $\mathrm{Pb}$.
\end{abstract}

\begin{abstract}
Abstrack: Natural fruit acids are fruits that taste sour containing organic acids, one of which is citric acid, examples of natural fruit acids are tamarind, lime, lemon, pineapple. Natural fruit acids can be used as an ingredient for soaking food derived from fishery products to get rid of the fishy smell and give the people a flavor of cooking. The purpose of this study was to determine the effect of immersion of natural fruit acids on the reduction of lead $(\mathrm{Pb})$ levels in Vanamae shrimp, to determine which immersion variations had the most effect on reducing lead levels in Vanamae shrimp. This study used an experimental method with a completely randomized block design (RAKL). The experiment was carried out with 5 treatments, namely Control (200 grams of shrimp without immersion), Treatment 1 (200 grams of shrimp $+25 \mathrm{ml}$ filtrate), Treatment 2 (200 grams of shrimp + $25 \mathrm{ml}$ of lime), Treatment 3 (200 grams of shrimp $+25 \mathrm{ml}$ filtrate lemon), and treatment 4 (200 grams of shrimp $+25 \mathrm{ml}$ filtrate), each treatment was given 4 times each. Based on the analysis of the anava test, the results obtained Fhit> Fdaf, It was concluded that there was an effect of immersion in natural fruit acids on reducing the levels of lead $(\mathrm{Pb})$ in Vaname shrimp meat, soaking with lime acid was the most significant to reduce the levels of lead metal $\mathrm{Pb}$.
\end{abstract}

Keyword: natural acid acid, vaname shrimp, lead metal

\section{How to Cite}

Sulistiawati, Devi, Hening Widowati, Widya Sartika Sulistiani. 2021. Pengaruh Variasi Perendaman Udang Vaname dalam Asam Buah Alami terhadap Penurunan Kadar Timbal (Pb) ditambak tradisional pasir Sakti Lampung Timur. Biolova 2(2). 134-143 
Tambak udang merupakan tambak yang dipergunakan untuk budidaya berbagai jenis udang yang berada pada daerah pesisir yang memiliki potensi ekonomi yang tinggi udang sebagai salah satu jenis produk perikanan yang banyak digemari oleh masyarakat, serta merupakan komoditas ekspor yang memiliki nilai jual yang tinggi.

Tambak Tradisional dalam budidayanya tidak menggunakan berbagai peralatan budidaya udang seperti geomembran dan aerator, sehingga beresiko dalam menurunkan kualitas air pada kolam budidaya mempengaruhi budidaya udang selain itu budidaya udang secara tradisional ini cukup beresiko dalam permasalahan pencemaran logam berat. Namun lingkungan tempat keberadaan budidaya udang dengan hutan mangrove berpengaruh pada kualitas udang yang dihasilkan hal ini dikarenakan mangrove merupakan salah satu tumbuhan yang berperan sebagai agen fitormediasi perairan serta "mangrove juga memiliki kemampuan yang disebut dengan biofilter yaitu kemampuan untuk menyaring, mengikat, dan menangkap polusi di alam berupa kelebihan sedimen sampah dan limbah buangan rumah tangga dan lainya. Fungsi ini berperan dalam meningkatkan kualitas air" Gunarto (2004); Walters Bradley B., et al (2008) dalam Utami (2018:143). Namun demikian meskipun kebaradaan lingkungan mangrove dapat meminimalisir cemaran pada perairan tetapi tetap ada resiko cemaran logam berat pada udang yang berasal dari sedimen tambak dan sumber makanan yang mengandalkan pakan alami, keberadaan tambak yang dekat dan jauh mangrove akan berpengaruh pada udang yang dihasilkan, sehingga penelitian ini berfokus pada tambak tradisional

Penelitian perendaman udang vaname (Litopenaeus vannamei) dalam asam buah alami terhadap penurunan kadar timbal $\mathrm{Pb}$ dilakukan di Tambak Tradisional yang berlokasi di daerah Pasir Sakti Lampung Timur, Merupakan dua jenis Tambak Tradisional yang memelihara jenis udang vaname (Litopenaeus vannamei) adalah dua tambak yang terletak di lokasi berbeda yaitu Tambak Tradisional Dekat Mangrove dan Tambak Tradisional Jauh Mangrove. Tambak Tradisional Dekat Mangrove dan Tradisional Jauh Mangrove merupakan petakan rawa mangrove atau kolam buatan yang langsung pada kolam tanah serta tidak ada lapisan geomembran, kedua tambak inipun tidak menggunakan aerator untuk menambah kelarutan oksigen dalam air. Tambak Tradisional Dekat Mangrove yang berada di daerah Pasir Sakti Lampung Timur berdekatan dengan hilir sungai yang dekat dengan laut sedangkan tambak tradisional jauh mangrove lokasinya dekat dengan lingkungan persawahan dan pemukiman penduduk.

Kedua jenis Tambak Tradisional dalam pengisian air tambak menggunakan sumber air yang berbeda, Tambak Tradisional Dekat Mangrove mengambil air yang berasal dari hilir sungai sedangkan tambak Tradisional Jauh Mangrove untuk mengisi air tambak dengan menggunakan air yang berasal dari irigasi persawahan. Perbedaan sumber air dan tempat serta lingkungan sekitar keberadaan mangrove inilah yang menjadikan berpotensi pencemaran logam pada perairan tambak yang mengkontaminasi udang vaname yang dibudidayakan pada Tambak Tradisional Pasir Sakti Lampung Timur, terutama cemaran logam timbal $(\mathrm{Pb})$.

Logam berat dapat mencemari berbagai sumber aliran air yang yang digunakan dalam aktivitas manusia salah satunya adalah sebagai tempat 
budidaya tambak. Hal inilah yang dapat menyebabkan tambak tradisional dapat beresiko mengalami pencemaran logam berat terutama timbal $(\mathrm{Pb})$. Karena banyaknyasumber cemaran logam berat timbal di Tambak Tradisional Pasir Sakti, berasal dari pipa-pipa yang dipasang sekitar tambak untuk mengganti air pada tambak sebulan sekali serta berasal dari gas buangan kapal kapal kecil milik nelayan yang menggunakan bahan bakar solar maupun bensin. Sumber cemaran logam timbal $(\mathrm{Pb})$ Tambak Tradisional Jauh Mangrove dapat berasal dari pipa-pipa yang terpasang sebagai pengganti air tambak, berasal dari pestisida, insektisida dan moluskisida yang yang digunakan pada persawahan yang terletak dekat dengan Tambak Tradisional Jauh Mangrove serta pembajakan sawah dengan menggunakan traktor dengan bahan bakar solar juga berpotensi dalam pencemaran logam timbal pada perairan.

Logam berat timbal yang dapat mencemari perairan terlarut dalam air dapat mengendap pada sedimen atau lumpur tambak. Logam berat yang mencemari tambak akan berbahaya bagi lingkungan karena sifat logam berat ini yang akumulasi dan tidak dapat diuraikan oleh organisme hidup, tetapi sebaliknya logamberat sebagai kontaminan yang berbahaya bagi organisme hidup terutama pada organisme yang dijadikan bahan konsumsi, seperti udang sedangkan udang yang bersifat filter feeder yang merupakan crustasea yang memakan organisme berupa plankton, siput-siput kecil, cacing kecil, anak serangga dan detritus (sisa hewan dan tumbuhan yang membusuk). Udang hidup di dasar perairan yang memiliki sifat filter feeder (memekan materi organik yang terlarut dalam air), pergerakan lambat dan lebih banyak hidup di dasar tambak pada sedimen tambak untuk mencari makan hal ini yang membuat udang yang berada pada tambak memungkinkan beresiko udang terkontaminasi oleh logam berat.

Hasil budidaya udang tambak tradisional pasir sakti yang biasanya dijual ke penampung udang sebagai komoditas ekspor juga sebagian dijual di pasar dan juga untuk konsumsi sendiri. Udang merupakan salah satu komoditas hasil tambak yang sangat diminati untuk konsumsi. Jika telah terkontaminasi oleh logam berat maka akan berbahaya bagi tubuh manusia dampak dari mengkonsumsi udang yang telah terkontaminasi tidak akan terlihat langsung setelah mengkonsumsi udang, tetapi efek akan dirasakan dalam jangka waktu lama karena sifat logam yang akumulatif, ketika logam masuk dalam tubuh dampak yang dapat ditimbulkan akibat akumulatif timbal dalam tubuh logam timbal bersifat toksik yang dapat menimbulkan keracunan.

Menurut Agustina (2014:63) menyatakan keracunan yang dapat ditimbulkan karena logam timbal $(\mathrm{Pb})$ : "Keracunan akut dapat terjadi jika timbel masuk ke dalam tubuh seseorang lewat makanan ataumenghirup uap timbel dalam waktu yangrelatif pendek dengan dosis atau kadaryang relatif tinggi. Gejala yang timbul berupa mual, muntah, sakit perut hebat, kelainan fungsi otak, tekanan darah naik, anemia berat, keguguran, penurunan fertilitas pada laki-laki, gangguan sistim saraf, kerusakan ginjal, bahkan kematian dapat terjadi dalam waktu 1-2 hari”.

Berbagai sumber cemaran yang terdapat di sekitar Tambak Tradisional Dekat dan Jauh Mangrove berpotensi tercemar logam berat timbal $(\mathrm{Pb})$. Logam timbal ketika masuk dalam tubuh manusia sangat berbahaya dan akan menggangu sistem yang ada pada dalam tubuh. Pada penelitian sebelumnya pun telah dilakukan 
berbagai usaha untuk menurunkan kadar logam timbal $(\mathrm{Pb})$ pada produk perikanan dengan cara pencucian dan pegolahan.

Menurut Widowati (2018:216) menyatakan bahwa : "Logam memasuki tubuh organisme bisa dengan berbagai cara, sehingga pada akhirnya memasuki organ atau sebatas pada permukaannya. Dengan demikian, mencuci dapat menjadi alternatif mengurangi logam berat yang menempel di permukaannya, sekaligus pada akhirnya terlarut dalam air cucian".

Logam berat yang menempel pada permukaan bahan makanan dapat dikurangi dengan cara pencucian sehingga logam dapat terlarut bersama dengan air cucian. Selain dengan pencucian dapat juga dilakukan pengolahan, Satrya (2019:60) "metode pengolahan direbus adalah metode pengolahan yang paling banyak menghilangkan kadar timbal diantara semua metode pengolahan (dikukus dan ditumis)". penelitian ini peneliti mencoba menurunkan kadar logam timbal $(\mathrm{Pb})$ sebelum dilakukan pengolahan, dengan melakukan berbagai perlakuan dengan variasi perendaman dalam asam buah alami yaitu berupa asam alami dari buah lemon, jeruk nipis, asam jawa dan nanas yang diambil sari buahnya.

Menurut penelitian Layani yang dikutip Sipa (2016:83) menyatakan: "Peredaman dengan larutan asam dapat mengikat logam oleh asam-asam organik yang terkandung didalam asam yaitu asam sitrat, asam askorbat, asam malat, asam format dan asam oksalat. Asam sitrat dapat mengikat ion-ion logam dalam penghelatan".

Berdasarkan pendapat Layani asam buah alami dengan jenis buah seperti lemon, jeruk nipis, asam jawa dan nanas memiliki kandungan asam organik yang tinggi, seperti asam sitrat maka ketika zat asam bertemu dengan ion logam maka terjadi pengelatan ion logam. Pengelat merupakan suatu kemampuan zat untuk mengikat ion-ion logam. Menggunakan asam sitrat karena bukan merupakan asam kuat yang dapat merusak tekstur dan rasa pada udang tetapi buah asam alami untuk meminimalisir kandungan logam berat timbal yang mungkin berada dalam daging udang. Buah lemon, jeruk nipis, asam jawa dan nanas. Buah-buahan tersebut merupakan buah yang biasanya tinggi vitamin $\mathrm{C}$ dan mengandung asam organik yaitu asam sitrat yang biasa digunakan sebagai minuman, bumbu tambahan masakan maupun penghilang bau amis pada produk perikanan. Buah-buahan tersebut digunakan karena senyawa asam dapat mengikat cemaran di antaranya logam seberat timbal $(\mathrm{Pb})$, sehingga logam pada produk perikanan dapat diikat oleh asam sitrat yang terkandung pada asam buah alami tersebut. Sehingga diharapkan, produk perikanan yang sempat tercemar, dapat meminimalisir cemarannya melalui bumbu yang pada awalnya dimaksudkan sebagai penghilang aroma amis, yang mengganggu konsumen bahan pangan perikanan. Hal ini juga didasari dari penelitian Sipa (2016:84) menyatakan "salah satu cara yang dapat dilakukan oleh masyarakat untuk menurunkan kadar logam dari makanan yang berasal dari laut atau perairan lainnya dapat melakukan perendaman terlebih dahulu dalam larutan asam jawa, asam cuka, filtrate nanas, belimbing wuluh dan jeruk nipis". Berdasarkan penelitian tersebut yang terbukti larutan asam dari buah yang mengandung asam sitrat dapat mengurangi kadar logam berat pada produk perikanan.

Hasil dari penelitian dibuat sebagai sumber belajar dalam bentuk poster pendidikan. Poster merupakan media informasi yang mengkombinasikan antara tulisan 
gambar atau kombinasi keduanya yang bertujuan untuk memberikan informasi kepada publik. Poster merupakan seni grafis dua dimensi yang mengkombinasikan antara angka, huruf, dan gambar yang dicetak dengan ukuran besar, poster dipasang pada keramaian kawasan sekolah yang bersifat memberi informasi. Poster yang dibuat merupakan poster pendidikan dikaitkan dengan materi pencemaran lingkungan, mengatasi mengurangi dampak pencemaran lingkungan pada produk perikanan yang dikonsumsi. Media poster yang dikembangkan juga dimanfaatkan sebagai sarana edukasi dan pengetahuan bagi masyarakat umum.

\section{METODE}

Penelitian ini menggunakan metode ekperimen, dengan Rancangan Acak Kelompok Lengkap (RAKL). Variable bebas dalam penelitian ini adalah pemberian asam buah alami, sedangkan variable terikatnya adalah penurunan kadar timbal $(\mathrm{Pb})$ yang terdapat di dalam daging udang. Penelitian ini terdiri atas 5 perlakuan dan 4 ulangan, yang masing masing ulangan terdapat 2 sampel. Perlakuan tersebut terdiri dari Kontrol (200 gram udang tanpa perendaman), Perlakuan 1 (200 gram udang direndam dalam $25 \mathrm{ml}$ asam jawa), Perlakuan 2 (200 gram udang direndam dalam $25 \mathrm{ml}$ jeruk nipis), Perlakuan 3 (200 gram udang direndam dalam $25 \mathrm{ml}$ jeruk lemon), dan Perlakuan 4 (200 gram udang direndam dalam $25 \mathrm{ml}$ nanas). Setiap perlakuan diberikan masing-masing ulangan sebanyak 4, dan setiap ualngan diberikan masing-masing sampel sebanyak 2. Dalam penelitian ini yang merupakan populasi adalah udang Vaname (Litopenaeus vannamei) di Tambak Tradisional Dekat dan Jauh Mangrove Pasir Sakti Lampung Timur.
Alat yang digunakan dalam penelitian ini adalah Nampan, Ember, Peniris, Baskom, Sendok, Timbangan, Botol Kecil, Pisau, Talenan, Gelas Ukur 25ml atau $10 \mathrm{ml}$, Plastik, Karet Gelang, Label, dan Pembungkus Wrap.

Bahan yang digunakan dalam penelitian ini adalah Sampel udang Vaname $1 \mathrm{~kg}$, Natrium Benzoate, Buah asam jawa dalam $5 \mathrm{ml}$ air perasannya (12,5\%), Buah jeruk nipis dalam $5 \mathrm{ml}$ air perasannya $(12,5 \%)$, Buah jeruk lemon dalam $5 \mathrm{ml}$ air perasannya $(12,5 \%)$, Buah nanas dalam $5 \mathrm{ml}$ air perasannya $(12,5 \%)$.

Tahapan penelitian ini dimulai dari: Tahapan (1). Menentukan tempat pengambilan sampel, dalam penelitian ini lokasi pengambilan sampel adalah di Tambak Tradisional Dekat dan Jauh dari Magrove Pasir Sakti Lampung Timur. Tahapan (2). Menentukan jumlah atau ukuran sampel yang akan diambil dari keseluruhan anggota, dalam penelitian ini sampel udang vaname diambil sebanyak 200 gram untuk sampel yang digunakan untuk ulangan 1, 2, 3 dan 4, masing-masing 100gram. Tahapan (3). Menentukan sampel yang dipilih secara acak, dalam penelitian ini sampel yang diambil dari tambak tradisional dekat dan jauh dari mangrove dengan cara dijala sehingga sampel yang didapat benar-benar acak, sampel ini mewakili seluruh populasi alam tambak, karena sampel oleh peneliti dianggap homogeny didasarkan umur udang yang sama pada tambak tradisional. Tahapan (4). Sampel udang yang dipilih direndam selama 15 menit menggunakan larutan asam buah alami sesuai perlakuan. Tahapan (5). Sampel udang yang telah direndam kemudian dianalisis peurunan kadar timbalnya, melalui uji Laboratorium. Pengujian/pengukuran kadar timbal dilakukan di Laboratorium Kimia Analisis, Universitas Muhammadiyah Malang. 
HASIL

telah dilakukan didapatkan hasil sebagai berikut:

Berdasarkan hasil uji analisis

kadar timbal pada daging udang yang

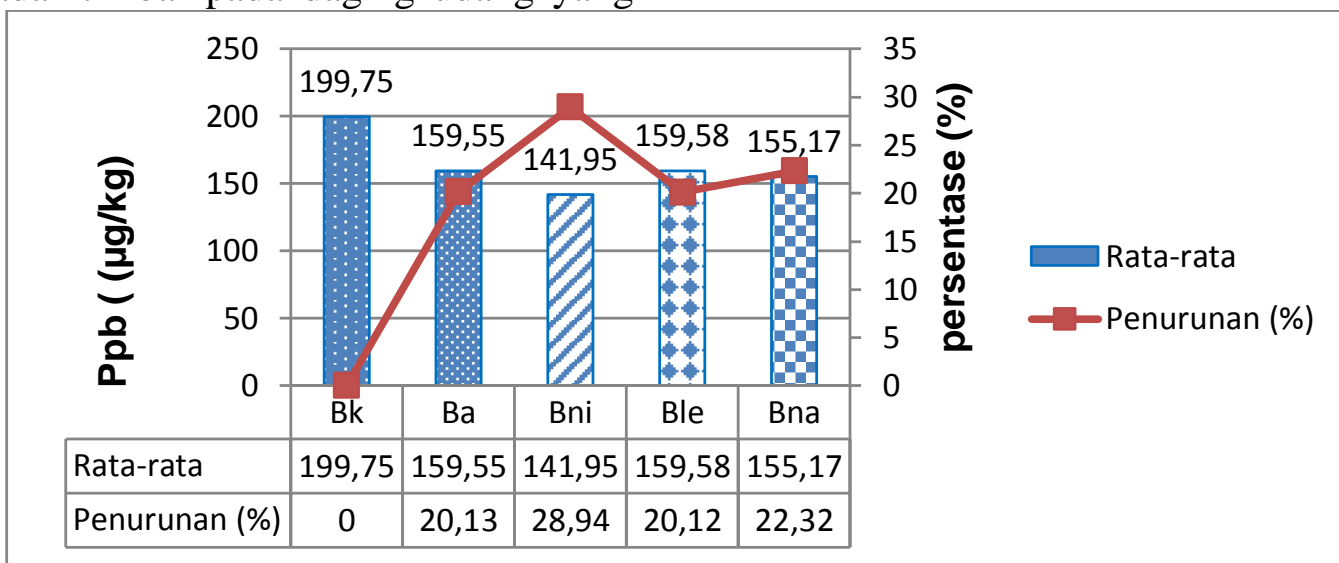

Gambar 1. Data Penurunan Kadar Logam Timbal Pb daging Udang Vaname Tambak Tradisional Dekat Mangrove

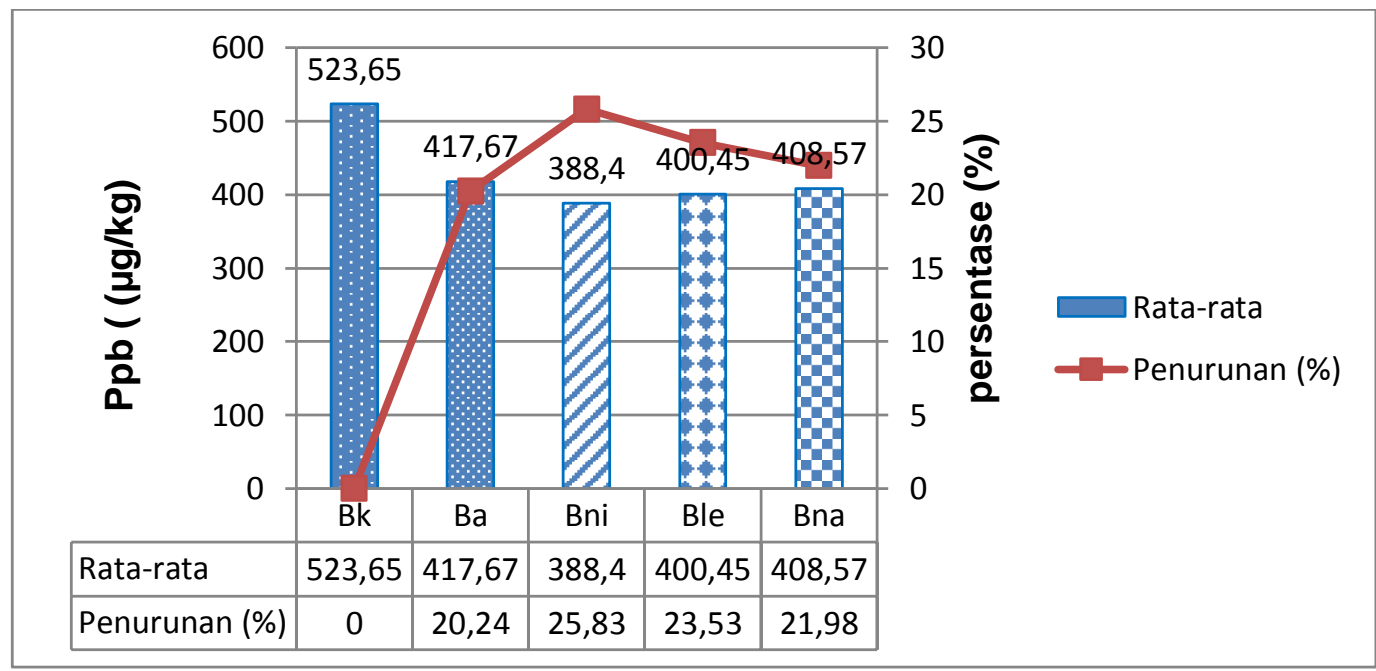

Gambar 2. Data Penurunan Kadar Logam Timbal Pb daging Udang Vaname Tambak Tradisional Jauh Mangrove

Keterangan :

B : Tradisional Dekat Mangrove

$\mathrm{Bk}$ : Udang Kontrol (Tanpa Perlakuan)

$\mathrm{Ba}$ : Udang dengan Perlakuan Perendaman Asam Jawa

Bni : Udang dengan Perlakuan Perendaman Jeruk Nipis

Ble : Udang dengan Perlakuan Perendaman Jeruk Lemon

Bna : Udang dengan Perlakuan Perendaman Nanas

PEMBAHASAN
Sampel daging udang yang digunakan pada penelitian ini berasal dari Tambak Tradisional Dekat dan Jauh Mangrove memiliki kadar logam yang berbeda. Kadar logam timbal pada sampel daging udang yang berasal dari Tambak Tradisional Dekat Mangrove memilki kadar logam timbal yang lebih sedikit dibandingkan dengan sampel daging udang yang berasal dari Tambak Tradisional Jauh Mangrove. Hal ini disebabkan letak tambak yang dekat dan jauh dengan mangrove, tanaman mangrove memiliki sifat 
fitoremediasi sehingga logam berat yang terlarut diperairan dapat terlebih dahulu terserap oleh tanaman mangrove. Utami (2018) menyatakan bahwa mangrove memiliki kemampuan untuk menyerap dan menyimpan logam berat dalam jaringan tubuh seperti pada akar, daun dan batang. Sehingga kadar logam timbal $\mathrm{Pb}$ pada Tambak Tradisional Dekat Mangrove tidak terlalu banyak seperti pada Tambak Tradisional Jauh Mangrove.

\section{Pengaruh Perendaman Asam Alami terhadap Kadar Timbal (Pb) pada Daging Udang Tambak Tradisional Dekat Mangrove dan Jauh Mangrove .}

Hasil penelitian berdasarkan analisis statistik sampel daging udang tambak tradisional dekat mangrove $\mathrm{F}$ perlakuan Fhit $=11132,17>$ Fdaft $=2,87$, sehingga perlakuan perendaman asam buah alami berpengaruh terhadap penurunan kadar timbal pada daging udang Vaname (Litopenaeus vanamei). Sampel daging udang tambak tradisional jauh mangrove $\mathrm{F}$ perlakuan Fhit $=1090,81>$ Fdaft $=2,87$, sehingga dengan demikian perlakuan perendaman asam buah alami berpengaruh terhadap penurunan kadar timbal pada daging udang vaname (Litopenaeus vannamei).

Penurunan kadar logam timbal yang terjadi pada daging udang tambak dekat dan jauh dari mangrove dapat terjadi karena diberikan perlakuan larutan asam dari asam buah alami. Asam buah alami mengandung jenis asam organic yang berupa asam sitrat yang mampu bertindak sebagai chelating agent yang mampu mengikat logam berat. Sehingga asam buah alami yang digunakan untuk perendaman udang vaname (Litopenaeus vannamei) mampu menurunkan kadar logam timbal $\mathrm{Pb}$. Asam sitrat sebagai chelating agent dengan tiga gugus fungsional karboksilnya yang dikondisikan dengan konsentrasi dan waktu kontak tertentu akan mengalami deprotonasi. Lepasnya ion $\mathrm{H}^{+}$yang potensial ionisasinya besar dapat masuk ke dalam kisi-kisi dan mampu menggantikan kedudukan dengan ion logam $\mathrm{Cd}^{2+}$ maupun $\mathrm{Pb}^{2+}$ dan terjadilah khelasi (Priyadi, 2013).

Asam sitrat menghelat logam berat timbal dengan Gugus fungsional karboksil - $\mathrm{COOH}$ yang terikat pada makromolekuler dalam asam buah alami akan terionisasi karena adanya perubahan konsentrasi dan membentuk muatan negatif, yang menyebabkan gugus fungsional tersebut akan bersifat aktif. Atom hidrogen pada gugus karboksil - $\mathrm{COOH}$ dapat dilepaskan sebagai ion $\mathrm{H}+$ atau mengalami deprotonasi, sehingga mempunyai peluang membentuk kompleks dengan ion logam, ion logam $\mathrm{Pb} \mathrm{2+}$ dalam udang dapat terlepas berikatan dengan gugus -COO- dari asam-asam buah alami dan membentuk khelat (IIyasa, 2016).

Berdasarkan kedua peryataan (Priyadi, 2013; Ilyasa, 2016) asam sitrat $\mathrm{C}_{6} \mathrm{H}_{8} \mathrm{O}_{7}$ dari asam buah alami memiliki kemampuan untuk mengkelat logam berat dengan tiga gugus karbaksilat dapat mengikat logam timbal $\mathrm{Pb}$ dengan gugus karboksil melepaskan proton menghasilkan ion sitrat, ion sitrat bereaksi dengan ion logam membentuk ikatan kompleks $\mathrm{Pb}$ sitrat $\left(\mathrm{C}_{12} \mathrm{H}_{10} \mathrm{~Pb}_{3} \mathrm{O}_{14}\right)$.

Penurunan kadar logam timbal yang ada pada tubuh udang disebabkan karena asam sitrat yang terkandung pada asam buah alami dapat merusak ikatan kompleks logam timbal $\mathrm{Pb}$ dengan protein pada tubuh udang. ion logam yang masuk pada tubuh organisme akan terikat dengan protein secara metaloenzim kadar logam $\mathrm{Pb}^{2+}$ 
dapat keluar karena lepasnya ikatan ion kompleks logam protein.

\section{Perlakuan Perendaman Asam Buah Alami dengan Pengaruh Terbaik}

$\begin{array}{crr}\text { Kedua Tambak } & \text { Tradisional } \\ \text { dengan lokasi } & \text { Dekat dan Jauh }\end{array}$
Mangrove memiliki kandungan timbal $\mathrm{Pb}$ yang berbeda, lokasi jauh mangrove lebih banyak mengandung logam berat timbal dibandingkan dengan lokasi dekat mangrove, namun penurunan kadar logam timbal yang terjadi setelah perendaman asam alami nilai penurunan yang tidak jauh berbeda.

Perlakuan asam buah alami yang paling berpengaruh signifikan untuk penurunan kadar timbal pada daging udang vaname dibanding dengan sampel kontrol (tanpa perlakuan) yaitu sampel perendaman asam buah alami jeruk nipis. Perendaman dengan jeruk nipis memberikan pengaruh paling signifikan dibandikan dengan asamasam buah alami yang lain. Kandungan timbal dengan perendaman asam jeruk nipis mampu menurunkan kadar timbal paling baik dan berpengaruh signifikan pada kadar logam timbal pada daging udang dikarenakan kandungan asam organik asam sitrat pada jeruk nipis memiliki kandungan asam sitrat yang tinggi. jeruk nipis mengandung asam sitrat yang cukup tinggi sekitar 8,7\% (Rukmana, 2015)

Nurmalasari (2015:171) dari hasil penelitiannya menyatakan bahwa: "Kerang yang direndam dengan air perasan jeruk nipis mengalami penurunan kadar $\mathrm{Pb}$ yang signifikan. Semakin lama kerang direndam maka kadar $\mathrm{Pb}$ nya semakin menurun. Penurunan disebabkan karena waktu perendaman yang lama kesempatan kontak antara logam dan asam semakin lama. Sehingga kesempatan asam untuk mengikat logam semakin lama".
Tambak Tradisional Dekat Mangrove pada gambar 12 sampel daging udang vaname perlakuan yang tidak banyak menurunkan kadar logam timbal $\mathrm{Pb}$ pada daging udang perlakuan perendaman dengan asam alami jeruk lemon. Menurut Hutasoit yang dikutip Harisman (2017:5) menyatakan Cairan buah lemon terdiri dari 5\% asam sitrat, yang memberikan rasa khas lemon dan pH-nya sekitar 2-3. Karena, jumlah asam sitrat lebih sedikit sehingga penurunan kadar logam tidak signifikan

Tambak Tradisional jauh Mangrove pada gambar 12 sampel daging udang vaname perlakuan perendaman asam alami yang tidak banyak menurunkan kadar timbal $\mathrm{Pb}$ pada daging udang vaname perlakuan perendaman dengan asam jawa. Menurut napitulu yang dikutip Solihah (2016:133) asam jawa mengandung $15 \%$ asam sitrat. Meski memiki kadar asam yang tinggi namun penurunan kadar logam paling sedikit dapat disebabkan karena penambahan air saat pengambilan larutan asam jawa dan juga asam yang digunakan merupakan asam yang dibeli dari pedagang telah mengalami berbagai pengolahan sehingga kadar asam sitrat dapat menurun.

\section{Pemanfaatan Hasil Penelitian Sebagai Media Pembelajaran Biologi}

Penelitian yang dilakukan mengenai pengaruh variasi perendaman asam buah alami terhadap penurunan kadar timbal $\mathrm{Pb}$ pada daging udang vaname (Litopenaeus vannamei) dikembangkan sebagai sumber belajar poster pendidikan yang dapat dimanfaatkan sebagai sumber informasi dalam pembelajaran biologi pada materi Dampak Pencemaran Bahan Pangan yang Berasal dari Perairan dan Solusi Penanganannya yang masuk pada materi kelas X KD. 3.11. Poster yang dikembangkan dibuat 
semenarik mungkin dengan memadukan antara gambar dan huruf dengan warna yang menarik. Poster yang dibuat berisikan hasil dari penelitian dengan komponen isi poster: 1) judul, 2) latar belakang, 3) tujuan, 4) metode penelitian, 5) langkah kerja, 6) hasil, 7) kesimpulan, 8) dampak, 9) solusi. Pembuatan sumber belajar poster sebagai pemanfaatan hasil penelitian hanya terbatas pada tahapan pengembangan yang dilakukan uji validasi oleh beberapa tim ahli dari Universitas Muhammadiyah Metro. Pengujian validasi poster antara lain, ahli desain dan ahli materi. Pengujian yang dilakukan oleh validator bertujuan untuk mengetahui kelayakan poster yang digunakan sebagai sumber belajar.

Sumber belajar poster yang telah dilakukan validasi kelayakan dengan pengisian angket oleh dosen ahli, ahli materi oleh bapak Suharno Zen, M.Sc dan ahli desain oleh bapak Rasuane Noor, S.Si., M.Sc. Berdasarkan hasil uji kelayakan mengenai sumber Belajar dengan produk berupa poster pendidikan, hasil validasi ahli materi memberikan komentar mengenai teks latar belakang untuk menyatukan teks keterangan yang menjelaskan keadaan Tambak Tradisional Dekat dan Jauh Mangrove untuk dijadikan menjadi satu poin dan pada teks tujuan memberikan tujuan smengenai dampak logam berat $\mathrm{Pb}$ dan solusi pengurangan kadar logam berat. Nilai hasil dari validasi dapat dilihat pada tabel15 dengan nilai persentase akhir sebesar 98\%, dengan nilai persentase tersebut kelayakan sumber belajar poster dapat dilihat pada tabel 29 skala likert kelayakan poster dengan rentang nilai $81 \%$ - $100 \%$ maka poster sangat layak digunakan sebagai sumber belajar.

Hasil uji kelayakan selanjutnya mengenai validasi desain poster pendidikan, dosen ahli memberikan komentar bahwa secara keseluruhan tampilan poster sudah menarik dan kombinasi antara huruf dan dan gambar sudah baik dan bagus. Nilai hasil validasi dapat dilihat pada tabel 16 dengan nilai persentase akhir sebesar $100 \%$ dengan nilai persentase tersebut kelayakan sumber belajar poster dapat dilihat pada tabel 3 skala likert kelayakan poster dengan rentang nilai $81 \%-100 \%$ maka poster sangat layak digunakan sebagai sumber belajar.

\section{KESIMPULAN}

Berdasarkan hasil penelitian yang telah dilakukan dapat disimpulkan bahwa variasi perendaman asam buah alami (asam jawa, jeruk nipis, jeruk lemon, dan buah nanas) berpengaruh terhadap penurunan kadar timbal $\mathrm{Pb}$ pada daging udang vaname. Metode perendaman daging udang vaname dengan asam buah jeruk nipis memiliki pengaruh terbaik dalam penurunan kadar timbal $\mathrm{Pb}$ pada daging udang vaname. Hasil penelitian yang dilakukan dibuat sebagai sumber belajar biologi dalam bentuk poster sangat layak digunakan dalam pembelajan biologi SMA kelas X KD. 3.11 Materi Pencemaran pada Bahan Pangan yang Berasal dari Perairan.

\section{SARAN}

Berdasarkan penelitian yang telah dilakukan maka terdapat beberapa saran untuk peneliti berikutnya.

Penelitian selanjutnya dapat melakukan pemanfaatan kearifan lokal dengan penambahan beberapa perlakuan asam buah alami, seperti buah belimbing wuluh dan jenis jeruk serta penambahan waktu dalam perendaman daging udang vaname (Litopenaeus vannamei) untuk penurunan kadar logam berat. 
1. Penelitian dapat dilakukan untukmenurunkan kandungan kadar logam berat selain timbal.

\section{DAFTAR RUJUKAN}

Agustina, T. 2014. Kontaminasi Logam Berat Pada Makanan dan Dampaknya Pada Kesehatan. Teknobuga, 1(1), h. 53-65.

Ilyasa,A., Eko Budi, S., Agung, T. P. 2016. Penurunan Kadar Ion $\mathrm{Pb} 2+$ dan $\mathrm{Cd} 2+$ Pada Kerang Dengan Menggunakan Filtrat Kulit

Nanas. Indonesian Journal of Chemical Science. 3(5), h. 211216.

Priyadi, s., Purnama, D., Umar, S., Pudji, H. 2013. Khelasi Plumbum $(\mathrm{Pb})$ dan Cadmium (Cd) Menggunakan Asam Sitrat pada Biji Kedelai. Agritech. 33 (4), h. 407-414.

Rukmana, R. 2017. Jeruk Nipis Prospek Agribisnis, Budidaya dan Pascapanen. Kanisius. Yogyakarta.

Satrya, B.R., Agus, S., Kartik, S., Hening, W. 2019. Pengaruh Variasi Pengolahan Cangkang Kerang Kijing Lokal (Pilsbryoconcha exilis lea) Terhadap Kadar Timbal dan Kalsium. Skripsi Tidak Diterbitkan. Lampung. Fakultas Keguruan dan Ilmu Pendidikan Universitas Muhammadiyah Metro.

Sipa, Y.N., Jamaludin., Ihwan. 2016. Pengaruh Jenis Asam Alami Terhadap Penurunan Kadar Logam Berat Timbal dalam Daging Ikan Teri (Stelophorus indicus sp) Asal Teluk Palu. Kovalen, 2(3), h.80-85.
Utami, R., Wini, R., kastana, S. 2018. Pemanfaatan Mangrove untuk Mengurangi Logam Berat di Perairan. Prosiding disajikan dalam Seminar Nasional Hari Air Dunia. Departemen Ekonomi Sumberdaya dan Lingkungan, Fakultas Ekonomi dan Manajemen, IPB: Palembang 20 Maret 2018.

Widowati, Hening., Agus, S., Widya,S.S. 2018. Keefektifan Pencucian Dan Pengolahan Untuk Mempertahankan Gizi Pangan Hewani Kawasan Pertanian Tercemar Logam Berat Pb. Prosiding Disajikan Dalam Seminar Nasional Publikasi Hasil Penelitian dan Pengabdian Kepada Masyarakat. Pascasarjana Pendidikan Biologi Dan Pendidikan Biologi S1, Universitas Muhammadiyah Metro. Lampung: Tahun 2018. 